\title{
Seismic Hazard and Ground Motion Characterization at the Itoiz Dam (Northern Spain)
}

\author{
A. Rivas-Medina, M. A. Santoyo, F. Luzón, B. Benito, J. M. Gaspar-Escribano, and A. García-Jerez
}

\begin{abstract}
This paper presents a new hazard-consistent ground motion characterization of the Itoiz dam site, located in Northern Spain. Firstly, we propose a methodology with different approximation levels to the expected ground motion at the dam site. Secondly, we apply this methodology taking into account the particular characteristics of the site and of the dam. Hazard calculations were performed following the Probabilistic Seismic Hazard Assessment method using a logic tree, which accounts for different seismic source zonings and different ground-motion attenuation relationships. The study was done in terms of peak ground acceleration and several spectral accelerations of periods coinciding with the fundamental vibration periods of the dam. In order to estimate these ground motions we consider two different dam conditions: when the dam is empty $(T=0.1 \mathrm{~s})$ and when it is filled with water to its maximum capacity $(T=0.22 \mathrm{~s})$. Additionally, seismic hazard analysis is done for two return periods: 975 years, related to the project earthquake, and 4,975 years, identified with an extreme event. Soil conditions were also taken into account at the site of the dam. Through the proposed methodology we deal with different forms of characterizing ground motion at the study site. In a first step, we obtain the uniform hazard response spectra for the two return periods. In a second step, a disaggregation analysis is done in order to obtain the controlling earthquakes that can affect the dam. Subsequently, we characterize the ground motion at the dam site in terms of specific response spectra for target motions defined by the expected values SA $(T)$ of $T=0.1$ and $0.22 \mathrm{~s}$ for the return periods of 975 and 4,975 years, respectively. Finally, synthetic acceleration time histories for earthquake events matching the controlling parameters are generated using the discrete wave-number method and subsequently analyzed. Because of the short relative distances between the controlling earthquakes and the dam site we considered finite sources in these computations. We conclude that directivity effects
\end{abstract}

Special issue on Deformation and Gravity Change: Indicators of Isostasy, Tectonics, Volcanism and Climate Change PAGEOPH. should be taken into account as an important variable in this kind of studies for ground motion characteristics.

\section{Introduction}

The Itoiz dam site is located at the Autonomous Community of Navarre, Northern Spain, $2 \mathrm{~km}$ north from Aoiz and $25 \mathrm{~km}$ east from Pamplona. The construction was finalized in 2003.

Its impoundment began in January 2004, and 8 months later, on 18 September, a clustered seismic series occurred with epicentre located between the city of Pamplona and the Itoiz reservoir. The mainshock $\left(M_{\mathrm{w}} 4.5\right)$ and the largest aftershock were widely felt in this region creating a great social expectation. After that, a large volume of local studies from different fields were performed to assess the dam safety (GARCíA-YAGÜE 2004; RuedA 2005; Herraiz 2005; Instituto Jaume Almera 2005; Ingenierta del Suelo 2005; Colegio de Ingenieros de Caminos, Canales y Puertos 2005; Colegio de Geologos 2005; GARCía-MAYORdomo and InsúaARÉvalo 2010). More recently, several studies about the seismicity and internal geophysical processes were published (RuIz et al. 2006a; Luzón et al. 2009, 2010; JiMÉNEZ et al. 2009; SANTOYo et al. 2010).

Two new regional-scale seismic hazard studies in regions containing the dam site have been carried out in recent years, in the frame of the ISARD and RISNA projects, respectively. The first is a European Interreg Project (see, SECANELl et al. 2008), aimed at standardizing the seismic hazard across borders, to resolve differences given by the French and Spanish building codes. The second is a local project (BENITO et al. 2008) addressing the seismic risk in Navarre province for definition of the emergency plan by Civil Defense. Both studies followed the PSHA 
methodology (Probabilistic Seismic Hazard Assessment) and provided different zonings and seismic catalogues. These studies gave results of the expected ground motion parameters, ranging between the values given by both seismic codes, and generally higher than the values given by the Spanish building code (see NCSE-02 2002).

Other issues to consider are that the dam is located at a site close to the boundary between France and Spain and the respective building codes provide very different values of PGA and response spectra in such a boundary. There are also differences in the seismic catalogues of both countries for the seismicity of Pyrenees.

This work provides a new contribution to the knowledge of this interesting site by presenting a new ground motion characterization, which may represent some realistic seismic scenarios with implications in the safety of the dam.

In a first part, we propose a methodology with different steps for reaching different approximations to the expected ground motion at the dam site, which may be applied to other cases. Secondly, we revise the geological and seismic characteristics at the dam site, as well as the technical aspects of the dam, in order to obtain the specific parameters for the application of the proposed methodology. This is finally applied at the Itoiz dam, allowing characterization of the ground motion with a detail according to the followed approach. The subsequent sections include particularities of the application and obtained results in each phase.

\section{Methodological Proposal for Ground Motion Characterization at the Dam Site}

As a first objective of this paper, we propose a methodology for characterizing the ground motion at dam sites, which will be applied in our case at Itoiz site, but may be followed for any other dam sites. The approach is structured in three different phases for reaching different approximations to the expected ground motion at the site, based on:

1. A seismic hazard analysis for establishing critical seismic scenarios related to the safety of the dam.
2. A disaggregation analysis for particular target motions linked to the previous scenarios and calculation of site-specific hazard-consistent spectra.

3. A detailed modeling of the source rupture and propagation for the computation of synthetic acceleration time-histories at the dam site.

In the first phase, a Probabilistic Seismic Hazard Assessment (PSHA) is proposed, including a logic tree with two nodes for capturing the epistemic uncertainty related to seismic zoning and groundmotion models. The choice of the return periods for the analysis PSHA must be conditioned by the characteristics of the application, but usually we recommend to take into account two earthquakes with their respectively probabilities: the project earthquake (PE), which represents the earthquake taken into account in the design of the dam and the extreme earthquake (EE), which may occur during its life time with a low probability.

The PSHA analysis will be carried out for the return periods (RP) corresponding to the $\mathrm{PE}$ and $\mathrm{EE}$ shocks, giving as results the Uniform Hazard Spectra (UHS) for both RP. Moreover, in each case the mean spectral values $\mu$ may be derived by combining the different branches of the logic tree, and the percentiles $16-84 \%$ may be also estimated by means of $\mu \pm \sigma$ acceleration values.

The UHS represents the contribution of different seismic actions in the hazard, but not to the ground motion associated to a specific earthquake. In order to characterize more specific ground motions, we propose to consider, for both earthquakes-PE and EEtwo dam conditions with different natural vibration periods: one corresponding to an empty dam (De) and another corresponding to a fully water-filled dam (Dwf). We can expect that the ground motions, which may represent some critical situations for the dam, have these spectral periods. The combination of the two earthquakes and the two conditions of the dam gives us four possible cases:

1. PE-De

2. PE-Dwf

3. EE-De

4. EE-Dwf. 
Each case represents a seismic scenario, characterized by the spectral acceleration SA at structural periods of the De or Dwf conditions $\left(T_{\mathrm{De}}, T_{\mathrm{Dwf}}\right)$ and return period of the PE and EE earthquakes. The ground motion for each scenario will be obtained in a subsequent step.

The second phase is aimed at determining the controlling earthquakes, which present the highest contribution to the previous seismic scenarios. Then we propose a disaggregation analysis in order to obtain the magnitude-distance-epsilon bin $\left(M_{\mathrm{w}}, r, \varepsilon\right)$ that provides (with highest probabilities) the target motions given by the obtained values of SA $\left(T_{\mathrm{De}}\right)$ and SA $\left(T_{\mathrm{Dwf}}\right)$ (here epsilon refers to the number of standard deviations considered in the ground motion prediction). These bins represent the controlling earthquakes for the dam. In a last step, the specific response spectra will be derived applying the ground motion models chosen in the PSHA analysis to the resulting $\left(M_{\mathrm{w}}, r, \varepsilon\right)$ bins.

In a last phase we propose to simulate the ground motions due to the controlling earthquakes in time domain, assuming a finite fault rupture embedded in a layered earth, with a given slip distribution, focal mechanism and rupture velocity. The rupture area $S$ for each earthquake may be estimated by some correlation between Magnitude $M$ and $S$ and using a suitable model of rupture. The synthetic accelerograms will be computed using the discrete wavenumber method described by BoucHON and AKI (1977) and BouchoN (1979) for point dislocations. In the modelization of ground motions, directivity plays a key role in the amplitude and time length of the surface motion. This can dramatically change the estimations of the peak ground accelerations and spectral amplitudes for a given site and earthquake depending on the fault orientation. In order to explore this, we propose to compute different sets of synthetic seismograms for several azimuths of the recording sites with respect to the fault.

\section{Characterization of the Dam Site}

\subsection{Geological and Geotechnical Conditions}

The Itoiz reservoir is located at central western Pyrenees. This is one of the most active areas in
Spain, after the south-southeastern part of the country (Benito and Gaspar-Escribano 2007), with about 35 events of magnitude $m_{\mathrm{b}} \geq 3.0$ recorded in instrumental times (Souriau and PaUCHeT 1998; Souriau et al. 2001). The Pyrenean range (Fig. 1) has resulted from the collision of the Iberian and Eurasian plates with a low convergence rate. The suture between the two plates, the North Pyrenean Fault (NPF), is characterized by a sharp Moho jump. Different geophysical studies since the 1980s reported a complex deep structure (GALLART et al. 1981; Ecors Pyrenean Team 1988; Daignières et al. 1994; Sourlau and Granet 1995; Pous et al. 1995) revealing the existence of a $10-15 \mathrm{~km}$ Moho jump beneath the trace of the NPF, which pointed to a major role of this structure in controlling the northward underthrusting of the Iberian plate beneath the thinner European plate.

The region where the Itoiz reservoir is located is a Mesozoic and Tertiary cover area composed by anticlines and synclines with the axes trending to the east, but truncated at some places by E-W to ESE-WNW fault systems (Puigdefabregas et al. 1978; García-SANSEGundo 1993; Ruiz et al. 2006a).

Geotechnical studies at the dam site show that it is constructed over a sequence of materials that run from calcareous marlstone to limestone down to about $30 \mathrm{~m}$, where a limestone basement is found. In order to estimate the subsurface $\mathrm{S}$-wave velocity at the Itoiz dam, we performed a field campaign in May 2009 to record seismic noise. We computed the coherence among the signals recorded in pairs of stations which were separated distances from $4.5 \mathrm{~m}$ up to $150 \mathrm{~m}$. Thus, using the two stations spatial autocorrelation method (see, e.g., Morikawa et al. 2004; Chávez-García et al. 2005, 2007; ChávezGARCÍA and LuZÓN 2005; RAPTAKIS and MAKRA 2010), we computed a phase velocity dispersion curve for Rayleigh waves, which was inverted using the computer codes by HERRMANn (1987) to obtain the $\mathrm{S}$-wave velocity model for the subsurface soil at Itoiz dam. In the inversion process we considered one fixed layer with $30 \mathrm{~m}$ depth overlaying the halfspace. The results showed S-wave velocities of $902 \mathrm{~m} / \mathrm{s}$ for the upper layer, and $1,736 \mathrm{~m} / \mathrm{s}$ for the halfspace, respectively. Thus, following the Spanish earthquakeresistant code (NCSE-02 2002) the soil surface of the 


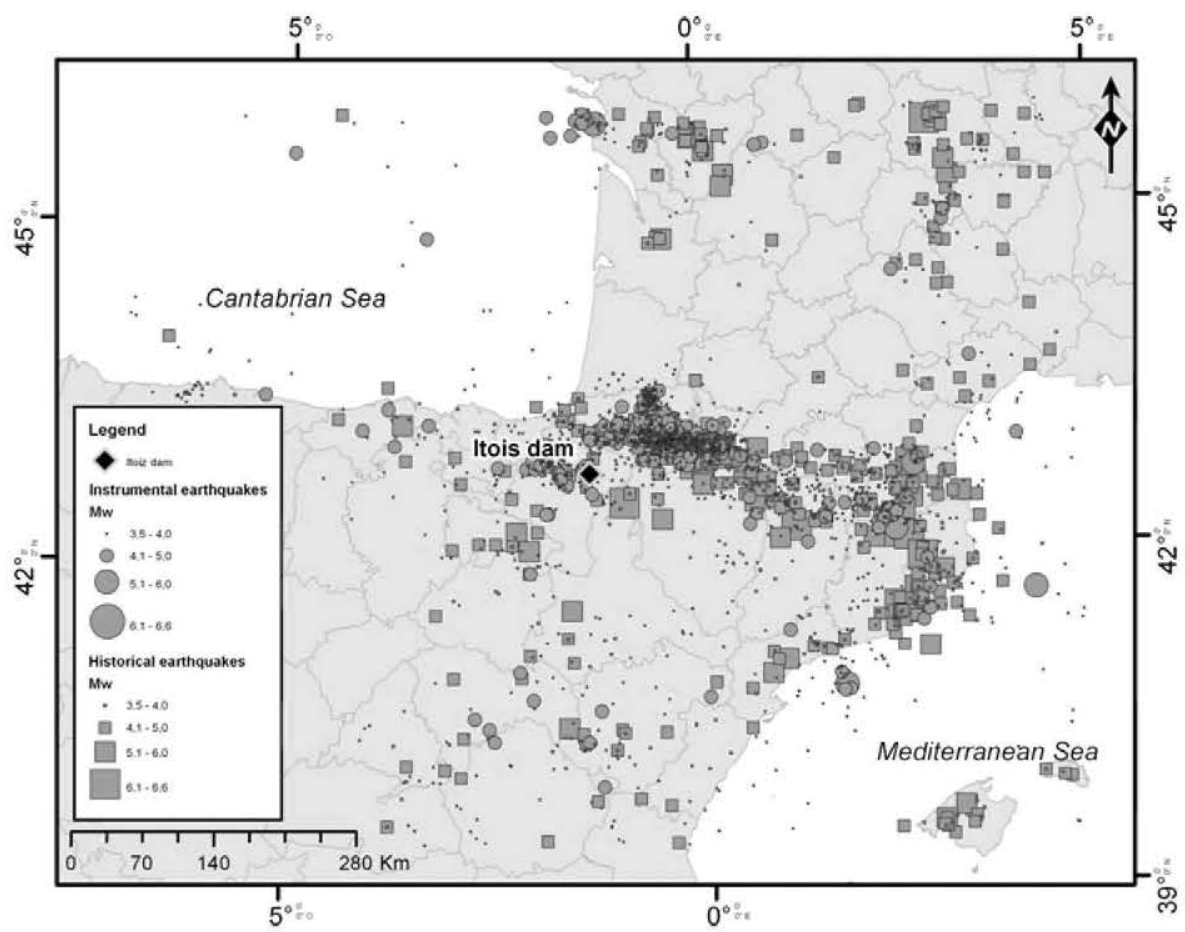

Figure 1

Seismicity catalogue used in the seismic hazard analysis. Datum European 1950, UTM H3ON

Itoiz dam can be considered as Soil Type I, that is hard rock.

\subsection{Dam Characteristics}

This dam, of concrete gravity type, is located in the Irati river (Navarre) and collects water from both the Urrobi and the Irati rivers. It has a height of $111 \mathrm{~m}$, a length of $525 \mathrm{~m}$ at the coronation and a capacity of $418 \mathrm{hm}^{3}$.

The fundamental vibration periods of the dam are $0.10 \mathrm{~s}$, for the empty dam (De), and $0.22 \mathrm{~s}$ for the water-filled dam (Dwf). These periods are taken from the study of the Colegio de Ingenieros de CAminos and CANALES Y Puertos (2005) and are obtained by dynamic response analyses of the dam structure, which take into account the seismic action by means of different ground motion time histories. This analysis follows the methodology of HATANAKA (1960), which is based on a cross section model of the dam.

The choice of the return periods for the analysis PSHA must be conditioned by the characteristics of the dam. The Itoiz dam is identified as Category A under the classification established by the Spanish Technical Regulation on Safety of Dams and Reservoirs (Moptma 1996). García-Mayordomo (2007) recommends the identification of two earthquakes: the project earthquake ( $\mathrm{PE}$ ), which represents the control earthquake, associated with a return period of 975 years, and another, called the extreme earthquake (EE), which identifies the seismic action considering a return period of 4,975 years. These recommendations are in accordance with the values indicated in the Technical guide for safety of dams (Guía TÉCNICA DE Seguridad de Presas 1999; Guía de Seguridad de Presas 2005) and will be adopted in our case.

\section{Ground Motion Characterization at the Itoiz Site}

According to the proposed methodology (described in Sect. 1) we adopt an approach structured in three phases for reaching different approximations to the expected ground motion at the site. The details and results of each phase are presented in following sections. 


\subsection{Probabilistic Seismic Hazard Analysis and Definition of Seismic Scenarios}

In a first step, a seismic hazard analysis was done following the PSHA methodology (e.g., BuDNITZ et al. 1997) based on zonation models. A logic tree with two nodes for capturing the epistemic uncertainty related to seismic zonings and ground-motion models was formulated. As a result, we obtain the PGA and spectral acceleration SA $(T)$ values for the two return periods considered in our analysis, 975 and 4,975 years, which characterize the ground motion due to the project and extreme earthquakes, respectively.

As inputs for the application of the PSHA methodology we prepared a seismic catalogue for this study (project catalogue) and selected different zoning and attenuation models after a careful revision of the literature. A logic tree with two nodes for capturing the epistemic uncertainty related to seismic zonings and ground-motion models is formulated.

Next, the weights of the different models that configure the branches of the logic tree are considered, with the criteria explained in the following sections. As a first result of this analysis, we obtain the uniform hazard spectra UHS with the adopted weight scheme.

\subsubsection{Seismic Project Catalogue}

Navarre is located in a border area between France and Spain. The majority of the seismicity in the western part of Pyrenees, affecting the study site, is concentrated on the French side. Then a combination of data from different catalogues including both countries must be taken in the hazard analysis.

We consider two catalogues developed in the frame of the ISARD project (SECANELL et al. 2008) in local magnitude, and RISNA project (BENTTO et al. 2008 ) in moment magnitude. A new project catalogue was created taking as initial database the information compiled in both catalogues. Since these catalogues included magnitude data given in different scales, a homogenization process was carried out for obtaining moment magnitude $M_{\mathrm{w}}$ as size parameter for all the
Table 1

Reference years estimated with the method by STEPP (1972) for different magnitude ranges derived from the completeness analysis of the seismic catalogue

\begin{tabular}{ll}
\hline Magnitude & Reference year \\
\hline$M_{\mathrm{w}}=3.5$ & 1,980 \\
$3.5<M_{\mathrm{w}} \leq 4.0$ & 1,962 \\
$4.0<M_{\mathrm{w}} \leq 4.5$ & 1,850 \\
$4.5<M_{\mathrm{w}} \leq 5.0$ & 1,750 \\
$5.0<M_{\mathrm{w}} \leq 5.5$ & 1,743 \\
$5.5<M_{\mathrm{w}} \leq 6.0$ & 1,477 \\
$6.0<M_{\mathrm{w}}$ & 1,150 \\
\hline
\end{tabular}

events. Applying the correlation (1) obtained with the common earthquakes found in the two catalogues.

$$
M_{\mathrm{w}}=0.8228 \cdot M_{\mathrm{L}}+1.0105\left(R^{2}=0.7834\right)
$$

The completeness of the catalogue was analyzed according to the methodology developed by STEPP (1972). The reference years from which the catalogue may be considered complete for each magnitude interval were estimated. With this purpose, we plotted the cumulative number of events of particular magnitude ranges through time. Abrupt increases of slope are associated with the reference year of completeness for that particular magnitude range (Tinti and Mulargia 1985). The identified reference years are listed in Table 1. A constant occurrence rate for each magnitude interval, calculated from the reference year to the present is assumed. These rates were used to solve the problem of completeness and to estimate the seismic parameters of the different zones for the whole analyzed period.

In a last step, a depuration process was developed, by removing fore- and aftershocks, because we assume a Poisson model for the seismicity of every zone. The project catalogue was de-clustered using the program SeriesBuster (Álvarez-Gómez et al. 2005) which allows us to identify seismic series considering the magnitude dependent time-space windows proposed by SECANELl et al. (2008).

The resulting project catalogue in terms of moment magnitude $\left(M_{\mathrm{w}}\right)$ is composed of a total of 3,086 events and is shown in Fig. 1 . 
Table 2 continued

\begin{tabular}{|c|c|c|c|}
\hline Zone & $M_{\mathrm{Wmax}}$ & $v_{0}$ & $\beta$ \\
\hline \multicolumn{4}{|c|}{ ISARD } \\
\hline 1 & 6.3 & 0.105 & 1.960 \\
\hline 2 & 5.9 & 0.317 & 3.027 \\
\hline 3 & 5.4 & 0.038 & 2.520 \\
\hline 4 & 6.5 & 0.363 & 2.308 \\
\hline 5 & 6.6 & 0.141 & 1.830 \\
\hline 6 & 5.2 & 0.042 & 3.035 \\
\hline 7 & 6.5 & 1.212 & 2.747 \\
\hline 8 & 6.3 & 0.302 & 2.462 \\
\hline 9 & 6.0 & 0.235 & 2.714 \\
\hline 10 & 5.0 & 0.055 & 3.784 \\
\hline 11 & 4.4 & 0.018 & 6.351 \\
\hline 12 & 4.9 & 0.042 & 4.157 \\
\hline 13 & 4.5 & 0.020 & 5.630 \\
\hline 14 & 6.2 & 0.095 & 2.021 \\
\hline 15 & 5.9 & 0.145 & 2.826 \\
\hline 17 & 6.1 & 0.052 & 1.833 \\
\hline 18 & 6.5 & 0.047 & 1.489 \\
\hline \multicolumn{4}{|c|}{ NCSE-02 } \\
\hline 19 & 5.5 & 0.085 & 2.888 \\
\hline 20 & 5.9 & 0.248 & 2.778 \\
\hline 21 & 6.5 & 1.216 & 2.792 \\
\hline 22 & 6.8 & 0.536 & 2.194 \\
\hline 23 & 6.4 & 0.322 & 2.316 \\
\hline 24 & 6.1 & 0.149 & 2.264 \\
\hline 25 & 6.7 & 0.087 & 1.571 \\
\hline \multicolumn{4}{|c|}{ RISNA } \\
\hline 1 & 5.4 & 0.154 & 3.616 \\
\hline 2 & 5.9 & 0.074 & 2.223 \\
\hline 3 & 5.4 & 0.028 & 2.235 \\
\hline 4 & 5.2 & 0.063 & 3.346 \\
\hline 5 & 6.2 & 0.136 & 2.151 \\
\hline 6 & 5.3 & 0.047 & 2.795 \\
\hline 7 & 6.0 & 0.149 & 2.441 \\
\hline 8 & 6.4 & 0.063 & 1.660 \\
\hline 9 & 6.7 & 0.217 & 1.950 \\
\hline 10 & 5.1 & 0.155 & 4.305 \\
\hline 11 & 6.0 & 0.075 & 2.067 \\
\hline 12 & 6.3 & 0.354 & 2.495 \\
\hline 13 & 6.5 & 1.235 & 2.769 \\
\hline 14 & 6.6 & 0.234 & 2.078 \\
\hline 15 & 5.4 & 0.123 & 3.224 \\
\hline 16 & 5.3 & 0.071 & 3.255 \\
\hline 17 & 4.9 & 0.066 & 4.398 \\
\hline 18 & 6.0 & 0.056 & 1.909 \\
\hline 20 & 4.7 & 0.032 & 4.520 \\
\hline 21 & 6.0 & 0.032 & 1.620 \\
\hline 22 & 4.4 & 0.022 & 6.851 \\
\hline 23 & 6.2 & 0.321 & 2.539 \\
\hline 24 & 6.2 & 0.197 & 2.338 \\
\hline \multicolumn{4}{|c|}{ GARONA } \\
\hline 1 & 5.8 & 0.017 & 1.470 \\
\hline
\end{tabular}

\begin{tabular}{llll}
\hline Zone & $M_{\text {Wmax }}$ & $v_{0}$ & $\beta$ \\
\hline 2 & 5.4 & 0.096 & 3.166 \\
3 & 5.5 & 0.118 & 3.004 \\
4 & 6.7 & 1.342 & 2.605 \\
5 & 5.2 & 0.195 & 4.149 \\
6 & 6.0 & 0.057 & 1.923 \\
7 & 6.0 & 0.094 & 2.204 \\
8 & 6.5 & 0.050 & 1.523 \\
9 & 4.7 & 0.057 & 5.248 \\
10 & 5.9 & 0.064 & 2.070 \\
& & & \\
$P C ~ N A V A R R A$ & & & 2.311 \\
1 & 6.0 & 0.131 & 2.846 \\
2 & 5.4 & 0.065 & 2.431 \\
3 & 6.2 & 0.219 & 2.812 \\
4 & 6.5 & 1.235 & 2.325 \\
5 & 6.8 & 0.727 & 2.927 \\
6 & 5.3 & 0.057 & 2.176 \\
7 & 6.2 & 0.140 & 4.942 \\
8 & 4.6 & 0.026 & 2.717 \\
9 & 6.2 & 0.449 & \\
\hline
\end{tabular}

$M_{w \max }$ maximum moment magnitude, $v_{0}$ earthquake occurrence rate above the threshold magnitude $\left(M_{\mathrm{wmin}}=4.0\right)$

\subsubsection{Seismic Zoning}

The probabilistic zoning method is suitable for areas with low to moderate seismicity such as the environment of the dam, where the lack of knowledge of the fault parameters prevents us from modeling its activity. In consequence, the seismicity is considered to be distributed in seismogenic zones, wherein uniform seismic potentials are assumed.

For this work we consider several suitable models for the area, as those used in: (i) the regulation of Garoña Nuclear Power Plant (NuClenor 1983) (Fig. 2a), (ii) the ISARD project (Fig. 2b), (iii) the hazard map of the Spanish Building Code (NCSE-02 2002) (Fig. 2c), (iv) the hazard analysis developed by Prospección E Ingeniería (1992) (Fig. 2d) and the RISNA project (Fig. 2e).

The seismicity of each zone and for each zoning is modeled by a doubly truncated Gutenberg-Richter model. The threshold magnitude was set to $4.0\left(M_{\mathrm{w}}\right)$ and a least-squares approach was used to derive the parameters $\alpha$ and $\beta$ according to the expression:

$$
\operatorname{Ln} N=\alpha-\beta \cdot M_{\mathrm{w}}
$$

The number $N$ of earthquakes exceeding a certain magnitude value was estimated by extrapolating the 


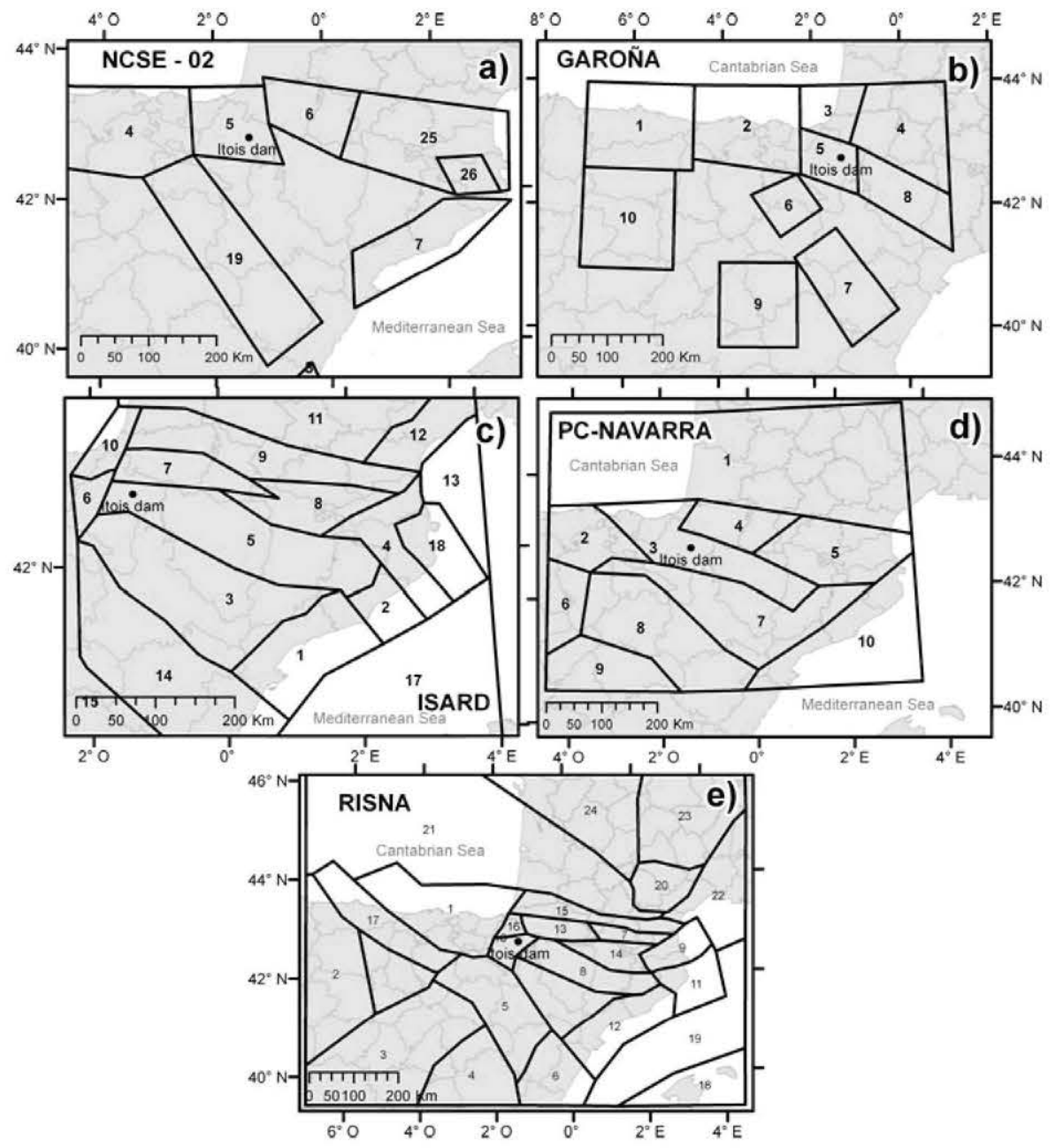

Figure 2

Zoning models included in the logic tree for the hazard analysis. a The GAROÑA zoning used for the hazard study at site of Garoña NPP (NUCLENOR SA, 1983). b The ISARD zoning. The unified zoning defined for the ISARD Project (SECANELL et al. 2008). c The NCSE-02 zoning. Defined for the hazard map of the Spanish building code (NCSE-02 2002). d The PC-NAVARRA zoning. The model used in the hazard analysis developed by Prospección e InGENIERía (1992). e The RISNA project zoning (Bento et al. 2008)

constant recurrence rates obtained within the completeness period to the entire period of study. The annual rate for the threshold magnitude is:

$$
v_{0}=N\left(M_{\mathrm{w}} \geq 4.0\right)=\mathrm{e}^{\alpha-\beta \cdot 4.0}
$$

Table 2 summarizes the values of $v_{0}$ and $\beta$ obtained for each zone considering the different zonings.

\subsubsection{Selection of Ground Motion Models}

The limited amount of strong motion data recorded at the dam and surrounding areas prevents us from developing strong motion models constrained with local data, so it is necessary to resort to models developed for other areas, provided that their characteristics are equivalent to the seismotectonic setting of the study area.

Recent models of strong motion with European data were developed by AmBrASEYs et al. (2005) and AKKAR and BOMMER (2007a, b), both requiring focal mechanisms. The recent New Generation Attenuation models (NGA-ABraHAMSON and SILVA 2007; Boore and AtKInson 2007; CAMPBell and Bozorgnia 2007; Chiou and Youngs 2006; IDRISS 2007) require also a very specific control of the 
rupture geometry and other details that are not usually available.

After a revision of the available models, analyzing their suitability for our area, we selected four attenuation laws: (1) BERGE-THIERRY et al. (2003) and (2) Lussou et al. (2001) used in the RISNA project, (3) Ambraseys et al. (1996) (used in the ISARD project), and (4) SABETTA and Pugliese (1996) based in European data and frequently used in studies

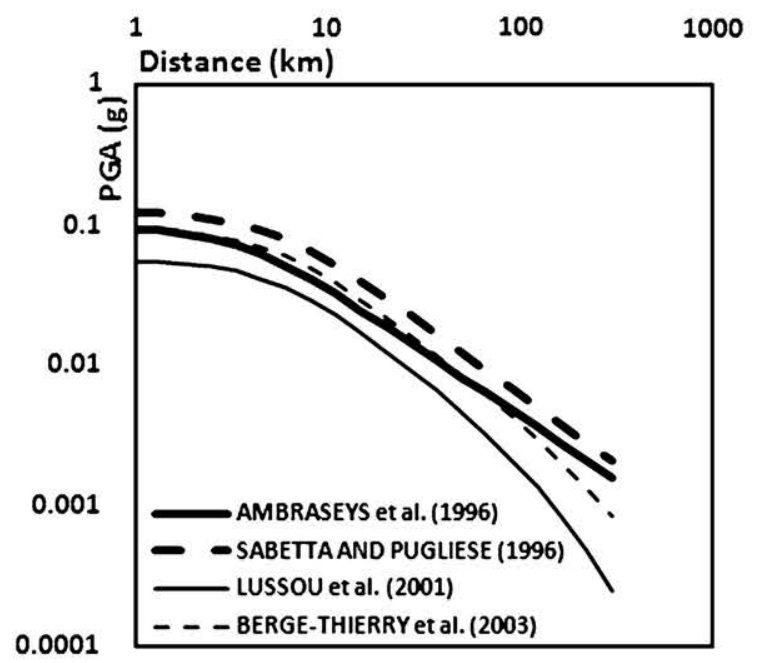

Figure 3

Graphical representation of the loss models for a moment magnitude earthquake of $M_{\mathrm{w}}=6$ used in the study of the Spanish territory. The other ground motion models developed with Spanish data, as CABAÑAS et al. (1999) and TAPIA (2006), are discarded either because they do not provide coefficients for spectral accelerations, or they do not cover a range of magnitudes suitable for our study (Fig. 3).

\subsubsection{Logic Tree}

We set up a logic tree composed of two nodes: seismic source zoning and ground-motion attenuation model (Fig. 4). The former node splits into five branches that stand for the five zoning models presented in a previous section. The scheme of weights follows the general criteria: models with more reliable seismic and tectonic information are considered with a higher weight. Thus, the higher weights correspond to the most recently developed models (RISNA and ISARD), and to the model of the Spanish building code.

The attenuation models of BERGE-THIERry et al. (2003) and Lussou et al. (2001) have been recently recommended by Drouet et al. (2007) for the Pyrenean area, and therefore, we assigned them a greater weight. On the other hand, the ground motion relations by SABeTtA and Pugliese (1996) and Ambraseys et al. (1996) were considered with lower weights.

\section{SOURCE MODEL}

GROUND MOTION MODEL

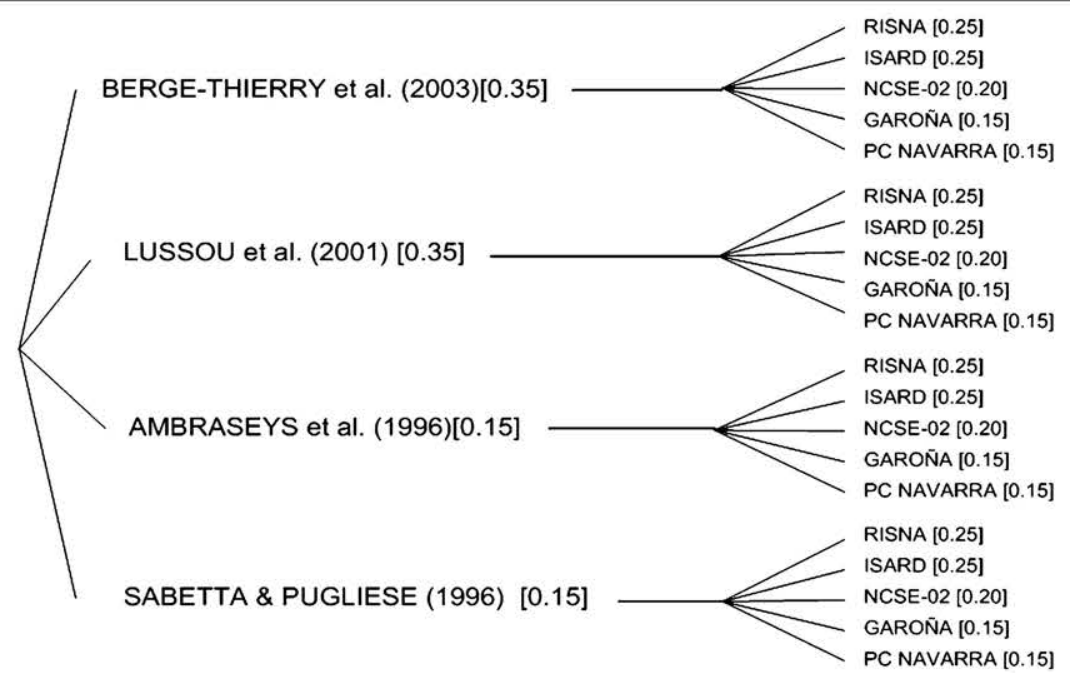

Figure 4

Logic tree used in the calculation of the hazard. The numbers in brackets are the weights assigned to each branch 


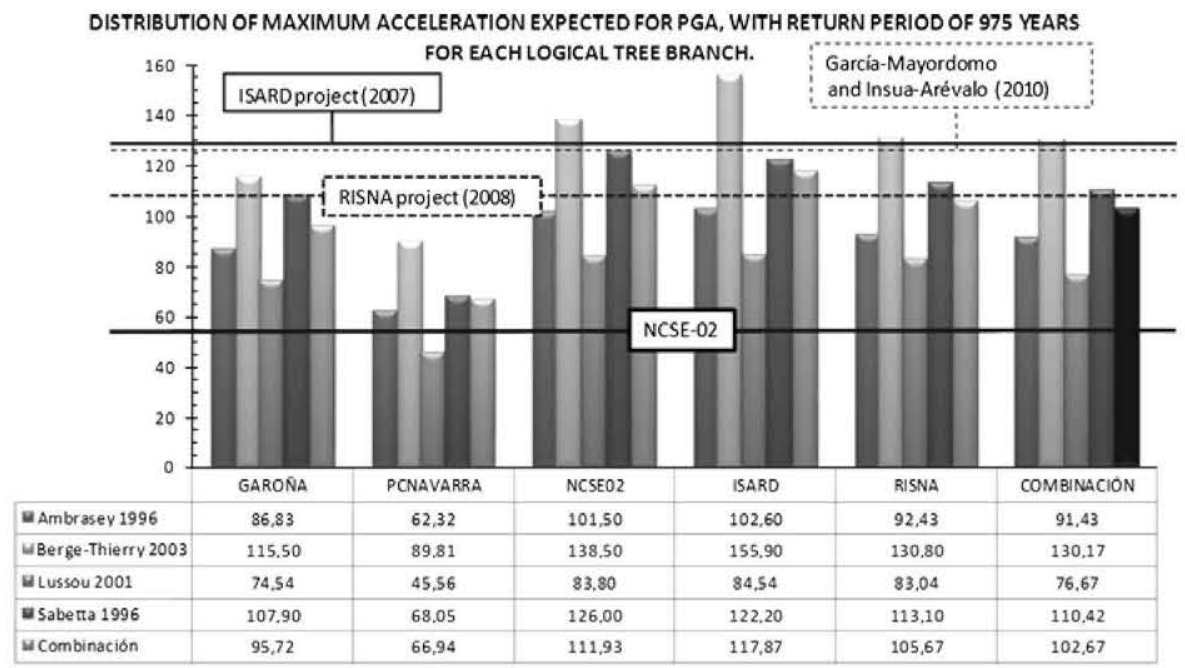

Figure 5

Distribution of maximum acceleration expected for PGA, with return period of 975 years for each logic tree branch (combined two by two). The results were compared with previous studies, NCSE-02 (2002), RISNA PROJECT (BENITO et al. 2008), ISARD Project (SECANELL et al. 2008) and García-Mayordomo and Insúa-ArÉvalo (2010)

Seismic hazard calculations for the different branches of the logic tree were carried out using the CRISIS2007 code (ORDAZ et al. 2007).

\subsubsection{Results: Uniform Hazard Spectra}

Figure 5 shows the combination of the final result of the logic tree with the partial results of each branch for PGA and a return period of 975 years. PGA values derived by other studies in the same area are also plotted. It is appreciated that the PGA values calculated in this study are clearly larger than the NCSE-02 (2002) values. This trend has been observed in previous recent studies (BENTTO et al. 2008; SeCANell et al. 2008; and García-Mayordomo and Insúa-ArÉvalo 2010).

The uniform hazard spectra (elastic, 5\% damping) at the dam site on hard rock sites considering different return periods ( 975 and 4,975 years) is shown in Fig. 6. They present maximum spectral
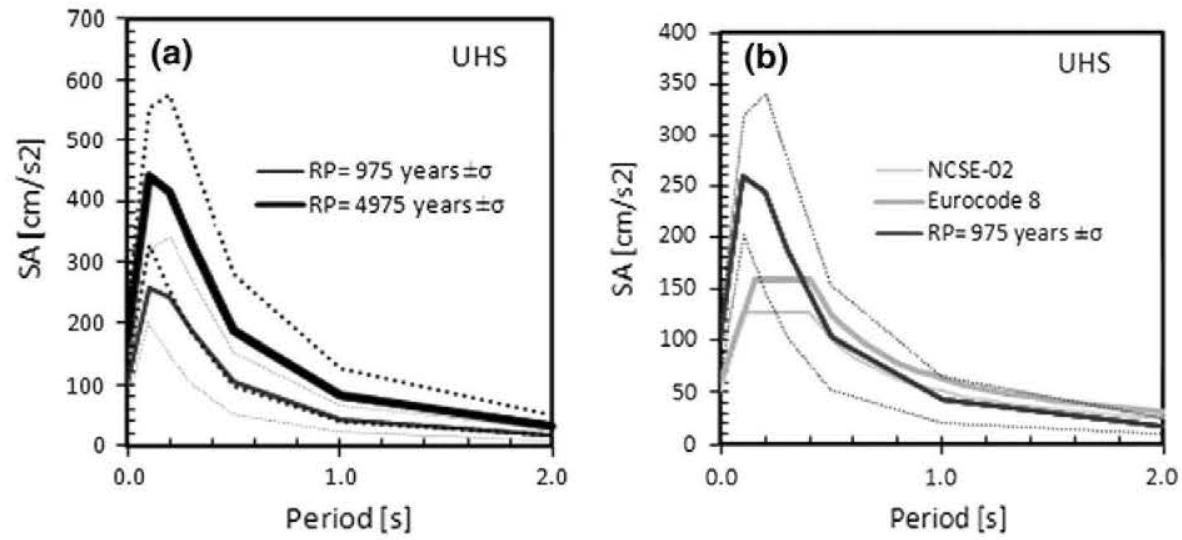

Figure 6

a Uniform hazard spectra at the Itoiz dam site on rock conditions considering different return periods ( 975 and 4,975 years) and your uncertainties. b Comparison the obtained response spectra for 975 years and the corresponding ones given in the Spanish and European seismic codes 
accelerations in the short-period range (around $0.15 \mathrm{~s}$ ), next to the fundamental periods of the empty dam $(0.1 \mathrm{~s})$, and the water-filled dam $(0.22 \mathrm{~s})$.

\subsection{Hazard Disaggregation Analysis, and Specific Site Spectra}

A disaggregation analysis is required in order to obtain the magnitude, distance and epsilon bins $\left(M_{\mathrm{w}}\right.$, $r, \varepsilon)$ with the highest contribution to the seismic hazard to determine the characteristics of the controlling earthquake.

As target motion for the disaggregation we take the expected spectral accelerations of the previous hazard analysis for conditions of the $\mathrm{PE}$ and $\mathrm{EE}$ shocks (RP 975 and 4,975 years), at the fundamental periods of the dam in empty $\left(T_{\mathrm{De}}=0.10 \mathrm{~s}\right)$ and water-filled $\left(T_{\text {Dwf }}=0.22 \mathrm{~s}\right)$ conditions. Then, we estimate the density functions of different bins to the motion represented by SA $(T)$ in the following scenarios:

1. PE-De; RP $=975$ years and $T_{\mathrm{De}}=0.1 \mathrm{~s}$

2. PE-Dwf; RP $=975$ years and $T_{\mathrm{Dwf}}=0.22 \mathrm{~s}$

3. EE-De; $\mathrm{RP}=4,975$ years and $T_{\mathrm{De}}=0.1 \mathrm{~s}$

4. EE-Dwf; $\mathrm{RP}=4,975$ years and $T_{\text {Dwf }}=0.22 \mathrm{~s}$

For each scenario we obtain the two controlling earthquakes which represent the largest hazard contribution and second largest hazard contribution to each ground motion. The resulting parameters are given in Table 3 . We can appreciate that all the controlling earthquakes are ranging between two extreme cases: a low magnitude and sort distance event $(M=4.5, \quad R=5 \mathrm{~km})$ and a moderate magnitude and intermediate distance shock $(M=6$, $R=30 \mathrm{~km}$ ).

The specific response spectra of the controlling earthquakes are obtained by application of the selected ground motion models to the values of the corresponding $\left(M_{\mathrm{w}}, r, \varepsilon\right)$ bins and are shown in Fig. 7. For filled dam condition, the spectrum of the stronger controlling event exceeds the spectrum of the weaker event for all periods for both, the project and the extreme earthquakes. However, for empty dam condition, short-period spectral accelerations are controlled by the lower-magnitude and near event while the long-period spectral accelerations are controlled by the higher-magnitude and more distant event.

\subsection{Simulation of Ground Motion in Time Domain}

\subsubsection{Modelling of Source and Propagation}

In the last phase of the proposed methodology we simulate the ground motions due to the controlling earthquakes in a time domain, assuming a finite fault rupture embedded in a layered Earth. For this purpose, a given slip distribution, focal mechanism and rupture velocity are required.

The rupture area for each earthquake was estimated by $\log (S)=M_{\mathrm{s}}-4.1$ (e.g., WeLLS 1994), where $S$ is the rupture area in $\mathrm{km}^{2}$, and $M_{\mathrm{s}}$ is the surface-wave magnitude. Rupture area was assumed rectangular with an aspect ratio of $L=W$ for earthquakes with $M_{\mathrm{s}} \leq 5.0$, and $L=2 W$ for earthquakes with $M_{\mathrm{s}}>5.0$ (e.g., DOWRICK and RHOADES 2004); here $L$ is the length along strike and $W$ is the width

Table 3

Hazard-consistent scenarios from PSHA for the dam

\begin{tabular}{|c|c|c|c|c|c|c|}
\hline & \multicolumn{3}{|c|}{ Largest hazard contribution (CE1) } & \multicolumn{3}{|c|}{ Second largest hazard contribution (CE2) } \\
\hline & Magnitude $\left(M_{\mathrm{w}}\right)$ & Distance $(\mathrm{km})$ & Epsilon & Magnitude $\left(M_{\mathrm{w}}\right)$ & Distance $(\mathrm{km})$ & Epsilon \\
\hline PE-D ${ }_{W F}$ & 4.5 & 10 & 1.6 & 5.0 & 25 & 2.2 \\
\hline$P E-D_{E}$ & 4.5 & 5 & 1.1 & 5.5 & 20 & 1.5 \\
\hline EE-D ${ }_{\mathbf{E}}$ & 4.5 & 5 & 1.5 & 6.0 & 25 & 1.5 \\
\hline EE-D $D_{\mathrm{WF}}$ & 5.0 & 15 & 2.2 & 6.0 & 30 & 2.0 \\
\hline
\end{tabular}

$P E-D w f$ project earthquake for the water-filled dam, $E E-D w f$ extreme earthquake for the water-filled dam, $P E-D e$ project earthquake for the empty dam, $P E-D e$ extreme earthquake for the empty dam 

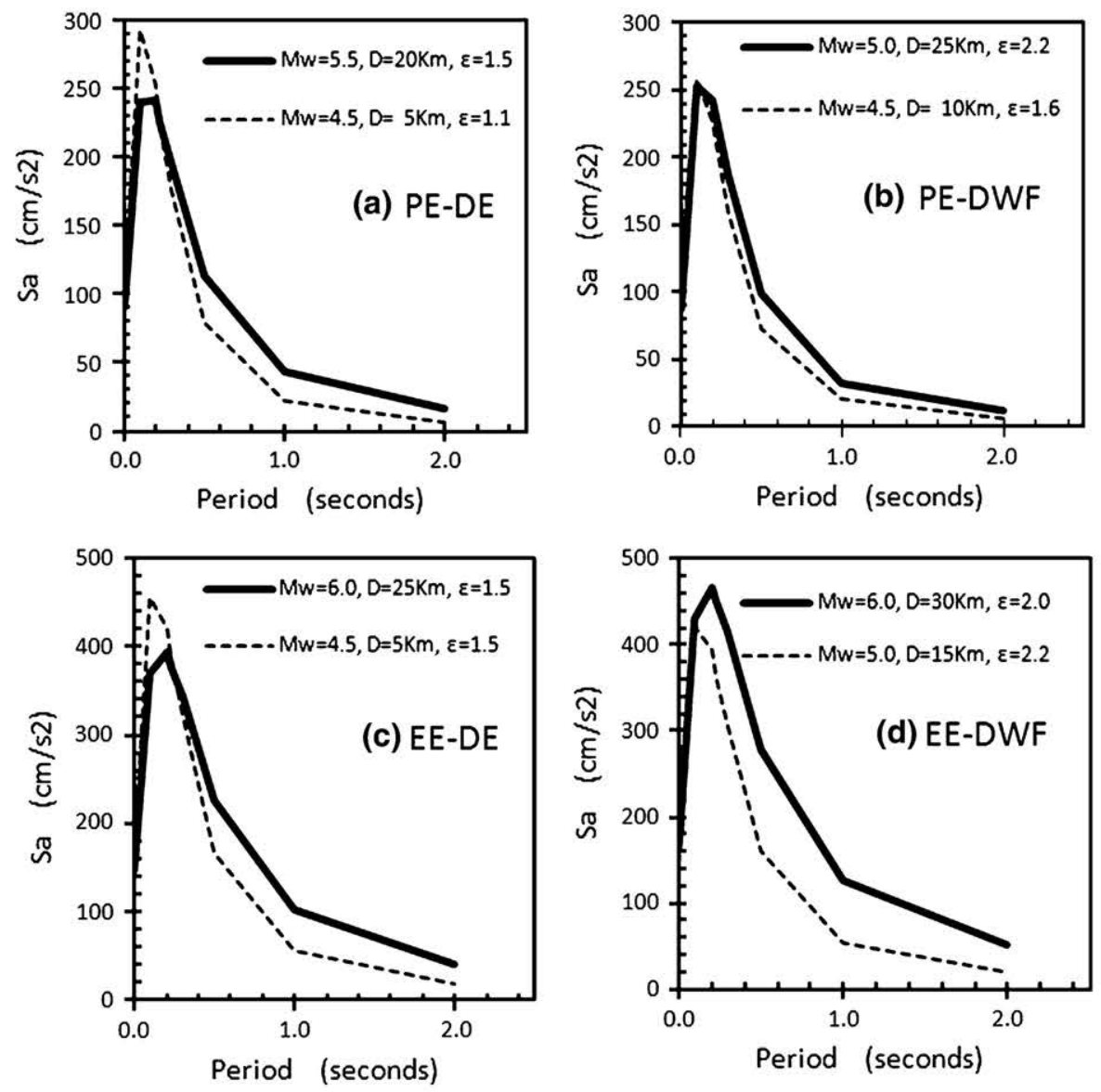

Figure 7

Specific response spectra from control earthquakes studied in this work. a $P E$-De project earthquake for the empty dam. b $P E-D w f$ project earthquake for the water-filled dam. c $E E$-De extreme earthquake for the empty dam. d $E E$ - $D w f$ extreme earthquake for the water-filled dam

along dip (Fig. 8a). The rupture area was discretized into $(N L, N W)$ square subfaults of equal size. For earthquakes $M_{\mathrm{s}} \leq 5.0, N L=N W=5$; for earthquakes $M_{\mathrm{s}}>5.0, N L=20$ and $N W=10$. A point dislocation source was located at the center of each subfault that releases the average moment of the entire subfault. The total moment release of each earthquake $\left(M_{\mathrm{o}}\right)$ is obtained by $\log \left(M_{\mathrm{o}}\right)=1.5 M_{\mathrm{w}}+$ 16.1 (e.g., Wells 1994). Here we assumed that $M_{\mathrm{w}}=M_{\mathrm{s}}+0.2$ given that in the magnitude interval modeled in this study $\left(4.5 \leq M_{\mathrm{s}} \leq 6.0\right)$ this relation is mostly linear (e.g., SingH and ORdaZ 1994). Slip distribution over the fault was assumed semielliptical (Miкuмо et al. 1998), tapered with a cosine function along the strike and dip directions (Figs. 7c, 8b). In this model, rupture nucleates at the hypocenter and propagates with constant velocity $V_{\mathrm{r}}$ from the nucleation point; here $V_{\mathrm{r}}=0.8 \beta$ and $\beta$ is the S-wave velocity at the source location (e.g., Мiкuмо et al. 1998). All subfaults share the same focal mechanism, which is also the same used to define the spatial setting of the fault ( $\varphi=$ strike and $\theta=$ dip angles). The synthetic accelerograms were computed using the discrete wave-number method described by BouchON and AKI (1977) and BouchON (1979) for point dislocations, and the crustal velocity structure used is that proposed for this part of Spain by Ruz et al. (2006b).

In order to explore if directivity plays a relevant role in the amplitude and time length of the surface motion we computed different sets of synthetic seismograms for several azimuth locations of the recording sites with respect to the fault. To assure a smooth rupture, the rise time $\left(\tau_{\mathrm{r}}\right)$ at each subfault was 


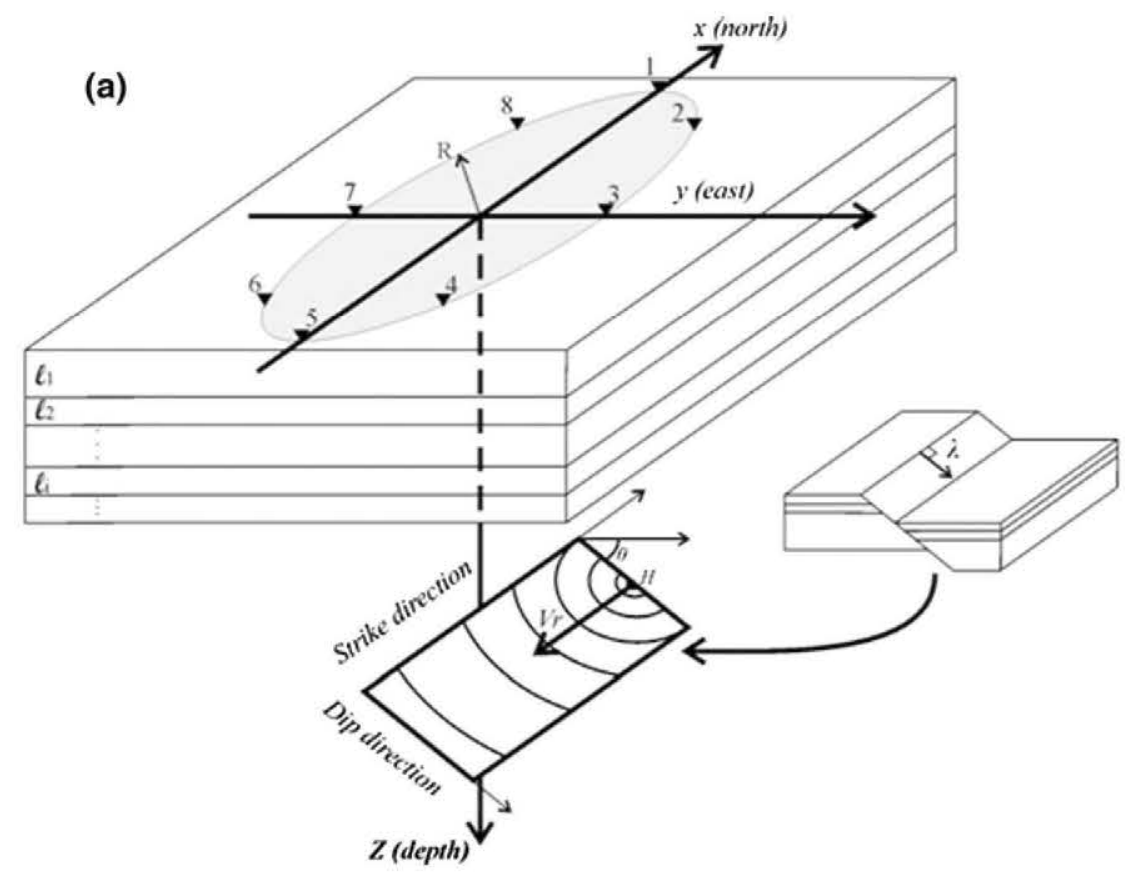

(b)

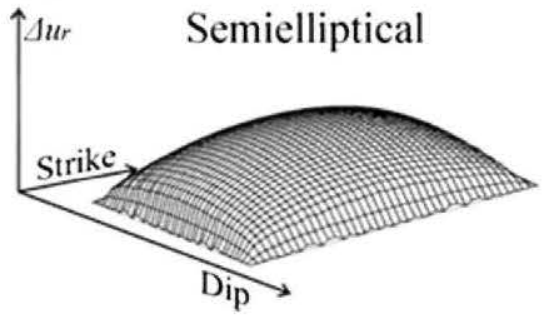

(c)

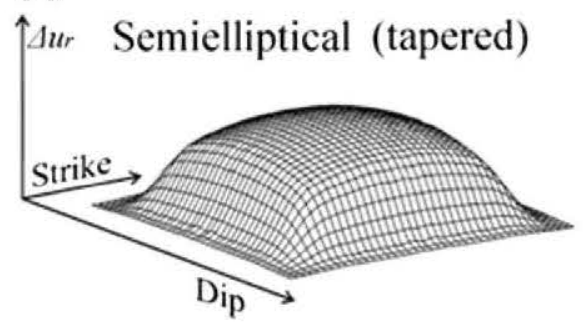

Figure 8

Diagram of the Earth's model, fault geometry and source properties for computations. a Diagram of the Earth's layered model and the relative location of the surface station array (numbered from 1 to 8 ), located on a circle with radio $\mathrm{R}$, centered on the origin. Layers are numbered from top to bottom $l 1, l 2, l 3$, etc. The fault plane (here shown as a rectangle on $z$ axis) is located below the array. The hypocenter (H) is located on the northern edge of the fault ( $+x$ direction). Rupture nucleates at the hypocenter and propagates with constant velocity $V_{\mathrm{r}}$ from the nucleation point. Rupture fronts propagate as circular patterns from the hypocenter. In this way rupture propagates mainly to the south ( $-x$ direction). We assume that all subfaults of the seismic fault share the same focal mechanism along the entire fault, which is also the same used to define the spatial setting of the fault ( $\varphi=$ strike, $\theta=$ dip angles). Rake angle of the slip vector $\lambda=-90$ describes a pure dip slip normal fault. b Semielliptical slip distribution along the fault. c Semielliptical slip distribution tapered on the edges with a cosine function along the fault

assumed to be at least $\tau_{\mathrm{r}} \geq \sqrt{2}\left(\Delta x / V_{\mathrm{r}}\right)$, where $\Delta x=\Delta y^{\prime}$ is the length of each subfault in the strike and dip directions, respectively.

\subsubsection{Synthetic Accelerograms}

We located eight computation sites, placed at the surface and at the same distance $R$ with respect to the center of the fault (Table 4 ), every $\pi / 4 \mathrm{rad}$, numbered in a clockwise sense and beginning with the station placed at the $+x, y=0$ (north) of the fault (Fig. 8a). The distances $R$ were defined based on the extreme earthquakes for an empty and a water-filled dam (Table 4). The hypocentral depth was set to $Z H=6.0 \mathrm{~km}$ for all the modeled earthquakes, which is the average for the zone (SANTOYo et al. 2010). Based on focal mechanisms published by RuEDA (2005) we set for the model a dip angle of $\theta=34^{\circ}$ 
Table 4

Earthquake source parameters used for the computation of the synthetic accelerograms

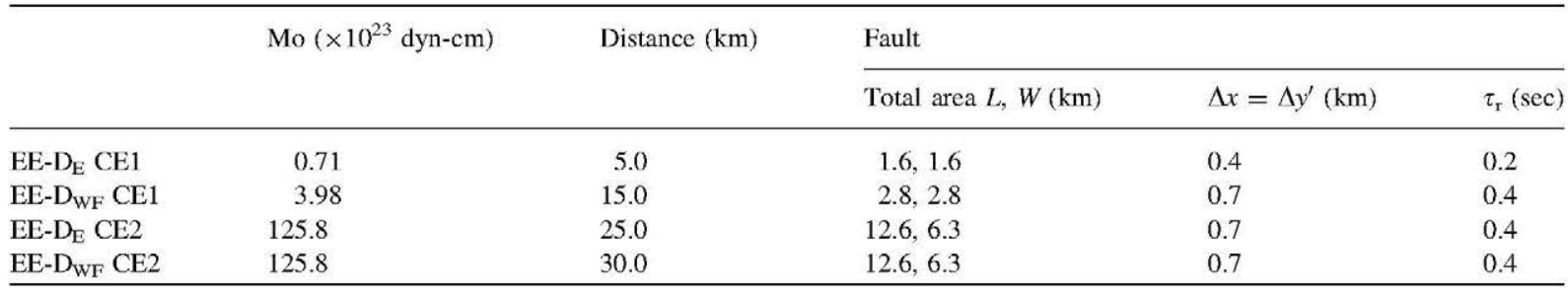

(a) $\mathrm{EE}-\mathrm{De}-1 \quad(M w=4.5 \quad \mathrm{R}=5.0 \mathrm{~km})$

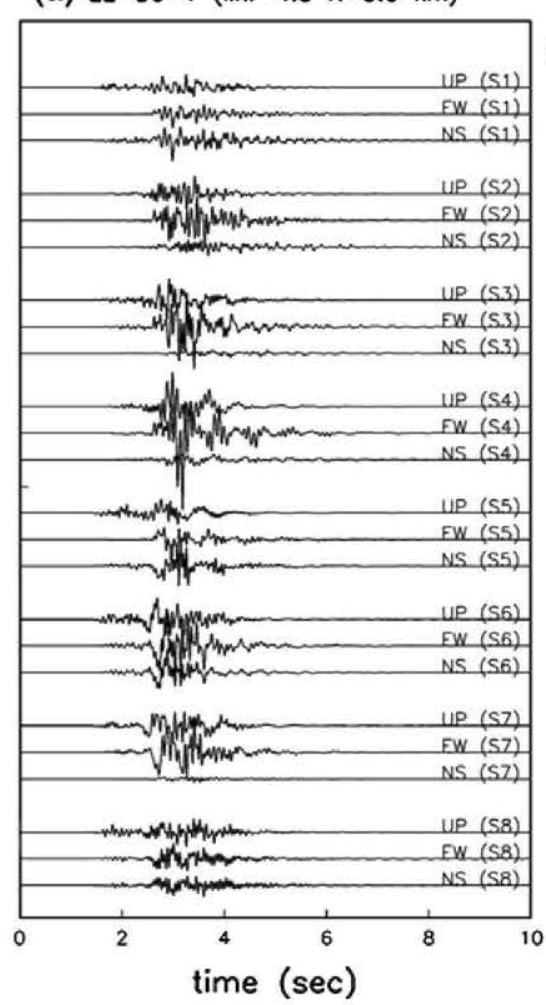

(b) $E E-D w f-2 \quad(M w=6.0 \quad R=30.0 \mathrm{~km})$

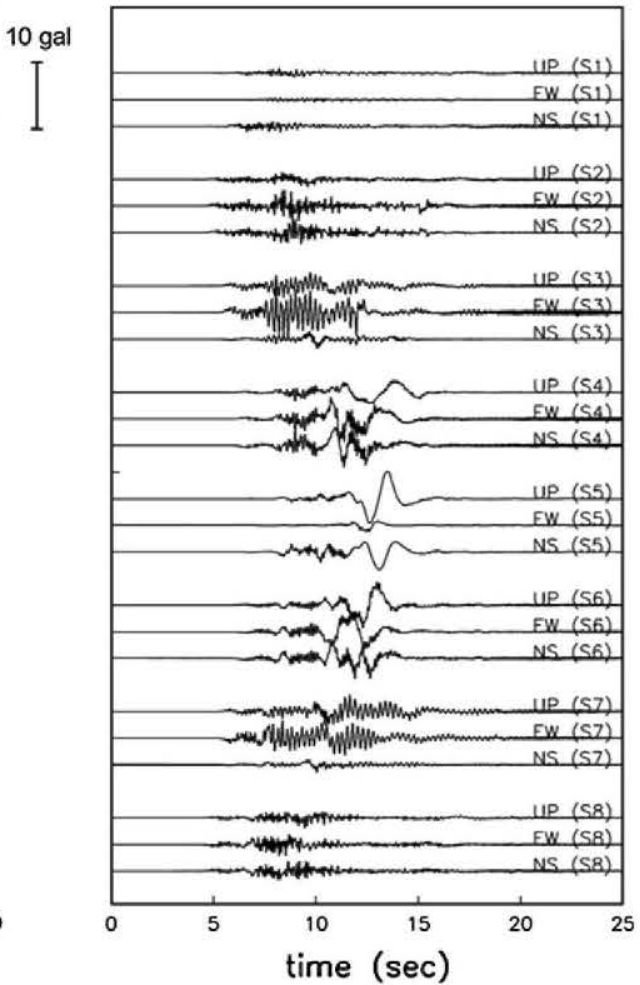

Figure 9

Synthetic accelerograms for the selected earthquakes. a Accelerograms for extreme earthquake EE-De-1. Waveforms from stations are numbered from 1 to 8 and components of motion N-S, E-W, Up are on the $x, y$, and $-z$ directions. b Accelerograms for extreme earthquake EE-Dwf-2. Waveforms from stations are numbered from 1 to 8 and components of motion N-S, E-W, Up are on the $x, y$, and $-z$ directions

and a rake angle of $\lambda=-90^{\circ}$. Strike angle in this model was set to $\varphi=0.0^{\circ}$ (Fig. 8a). The convention used for the component of ground motion $(\mathrm{N}-\mathrm{S}$, E-W, Up) is shown in Fig. 8a.

In Fig. 9 we show the synthetic accelerograms obtained for two of the extreme earthquakes considered, showing the station and component of motion $(\mathrm{N}-\mathrm{S}, \mathrm{E}-\mathrm{W}, \mathrm{Up})$. We depict here the results for the more nearby and distant controlling earthquakes to the dam. On the left hand side of this figure, we show the accelerations produced by an earthquake with magnitude $M_{\mathrm{w}}=4.5$ at a distance of $5.0 \mathrm{~km}$, and on the right hand side we show results for an earthquake with magnitude $M_{\mathrm{w}}=6.0$ at a distance of $30.0 \mathrm{~km}$. As expected, peak ground accelerations at stations located in the rupture direction are larger than in stations located on the opposite side. Amplitudes at stations 4 and 5 , are in both cases about three times 
(a) $\mathrm{EE}-\mathrm{De}-1(\mathrm{M}=4.5 ; \mathrm{R}=5.0 \mathrm{~km})$
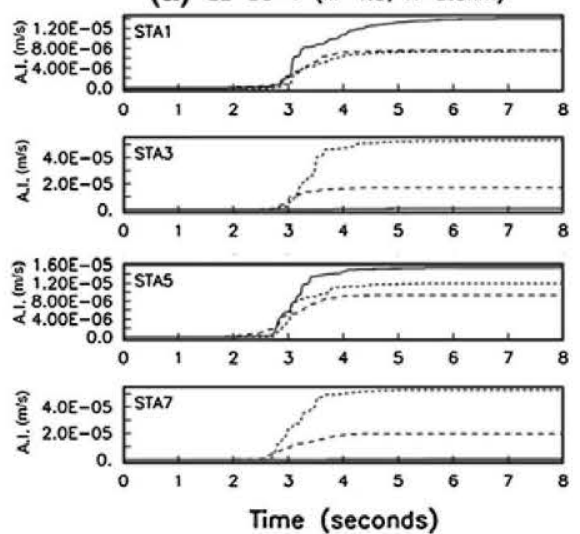

(b) $\varepsilon \varepsilon-D w f-2(M=6.0 ; R=30 \mathrm{~km})$
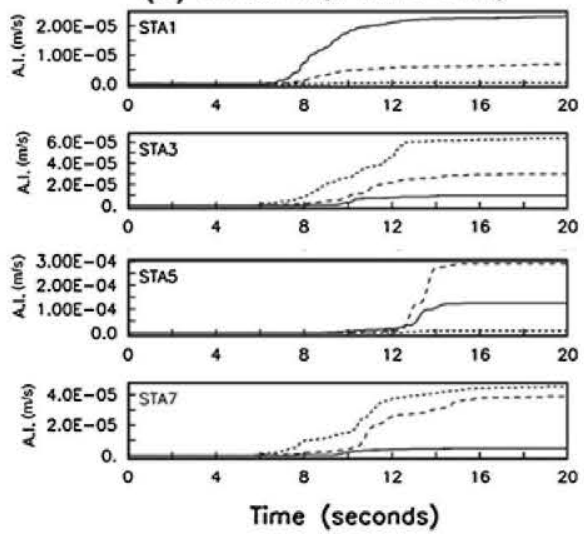

Figure 10

Arias Intensity plot versus time for both earthquakes shown in Fig. 8 and stations 1,3,5 and 7. N-S component of motion is shown by solid line, $\mathrm{E}-\mathrm{W}$ component is shown by a dashed line and Up component is shown by dotted line. a EE-De-1 extreme earthquake for the empty dam. b $E E-D w f-2$ extreme earthquake for the water-filled dam

larger than amplitudes at stations 1 and 8 . In the same sense, the pulse width and duration at stations located in the rupture direction are shorter than on stations placed on the opposite direction. From these results it is clearly observed that the pulse width and amplitude of waveforms on accelerograms vary depending on the angle between the rupture direction and the take off angle to the station. In Fig. 10, we show the evolution of the Arias Intensity (AI, ARIAS 1970) with respect to time in four of the observing stations $(1,3$, 5 , and 7) computed from the synthetic accelerograms. A rapid change of $\mathrm{AI}$ can induce stronger effects at surface than a slower one. For the EE-Dwf-2 earthquake (Fig. 10b), the change of the AI on station 5 is steeper than on the other stations, implying that in this case, both the waveform amplitudes and pulse width have similar importance on the surface motion.

On Fig. 11 we show the response spectra for the selected stations and earthquakes. Here it can be observed that stations located on the rupture direction have larger maximum spectral amplitudes that the ones located at the opposite direction and that spectral amplitudes for periods of interest for the dam ( 0.1 and $0.22 \mathrm{~s})$ have their largest amplitudes at the perpendicular direction to the rupture plane, which is an unexpected result. Spectral amplitudes can present differences of as much as four times.

\section{Discussion and Conclusions}

We present in this paper a methodological approach for characterizing the ground motion that may represent some realistic seismic scenarios at Itoiz dam. Several forms of hazard-consistent ground motion characterization are presented as result of a full site-specific PSHA analysis, carried out for two return periods, 975 and 4,975 years, following the Spanish Technical Regulation on Safety of Dams and Reservoirs (MoptMA 1996). These periods are associated with two earthquakes, which may affect, at different levels, the security of the dam, namely the project earthquake $(\mathrm{PE})$ and the extreme earthquake (EE). Uniform hazard spectra (UHS) were derived as result of a first part of the analysis, giving values of PGA 0.10 and $0.17 \mathrm{~g}$ for these return periods, and maximum spectral acceleration of SA $(0.1)=0.27 \mathrm{~g}$ and SA $(0.1)=0.44 \mathrm{~g}$, respectively. These values are higher than the ones given by the Spanish Building Code NCSE-02, and in an approximate agreement with the values obtained from different studies for the region.

A more detailed ground motion characterization was done in a second step, considering specific seismic scenarios that may represent critical actions for the security of the dam. These scenarios were identified taking into account both $\mathrm{PE}$ and $\mathrm{EE}$ 

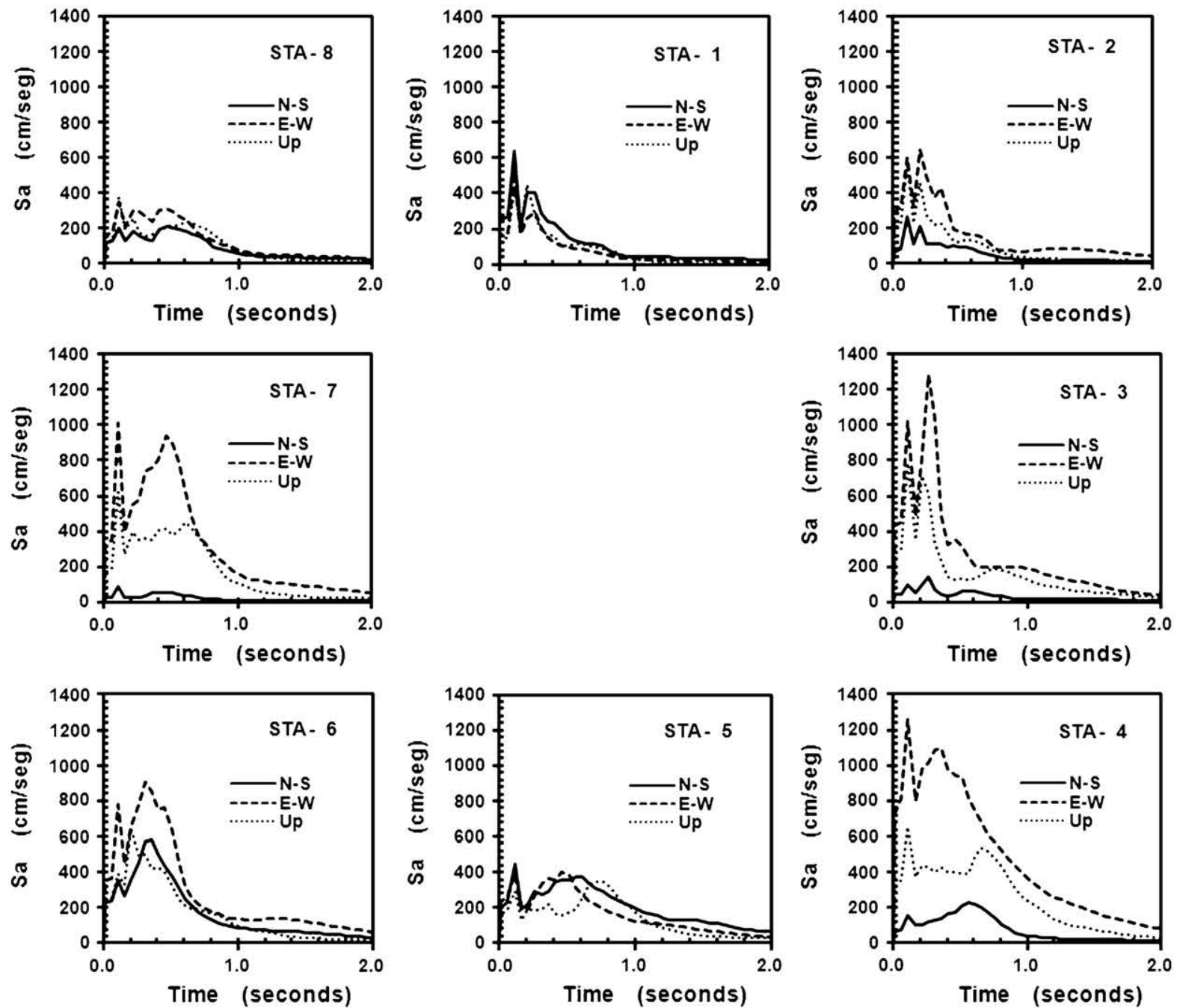

Figure 11

Response spectra for both earthquakes shown in Fig. 8 and all stations. N-S component of motion is shown by solid line, E-W component is shown by a dashed line and Up component is shown by dotted line. a EE-De-1 extreme earthquake for the empty dam. b EEDwf-2 extreme earthquake for the water-filled dam

earthquakes, and two stages of the dam, empty and water-filled conditions, with fundamental periods of 0.10 and $0.22 \mathrm{~s}$, respectively. A disaggregation analysis was developed for obtaining the control earthquakes linked to the four scenarios, each one identified by a possible combination of return period and structural period. The spectral accelerations SA ( $T$ ) for the structural periods of $T_{\mathrm{De}}=0.10 \mathrm{~s}$ and $T_{\text {Dwf }}=0.22 \mathrm{~s}$, were taken as target motion for the disaggregation analysis. Earthquakes in a range of magnitude $M_{\mathrm{w}} 4.5-6$ and distance $5-30 \mathrm{~km}$ were identified as control earthquakes. We obtained specific response spectra (SRS) for these events, which may be considered a second approximation to the ground motion that may affect the dam.

The SRS are narrower than the UHS previously derived but similar maximum spectral accelerations are found in both types of spectra, around $250 \mathrm{~cm} /$ $\mathrm{s}^{2}$ (PE) and $450 \mathrm{~cm} / \mathrm{s}^{2}$ (EE). These maximum values are found in a period range (0.1-0.2 s) in agreement with the fundamental periods of the dam. 

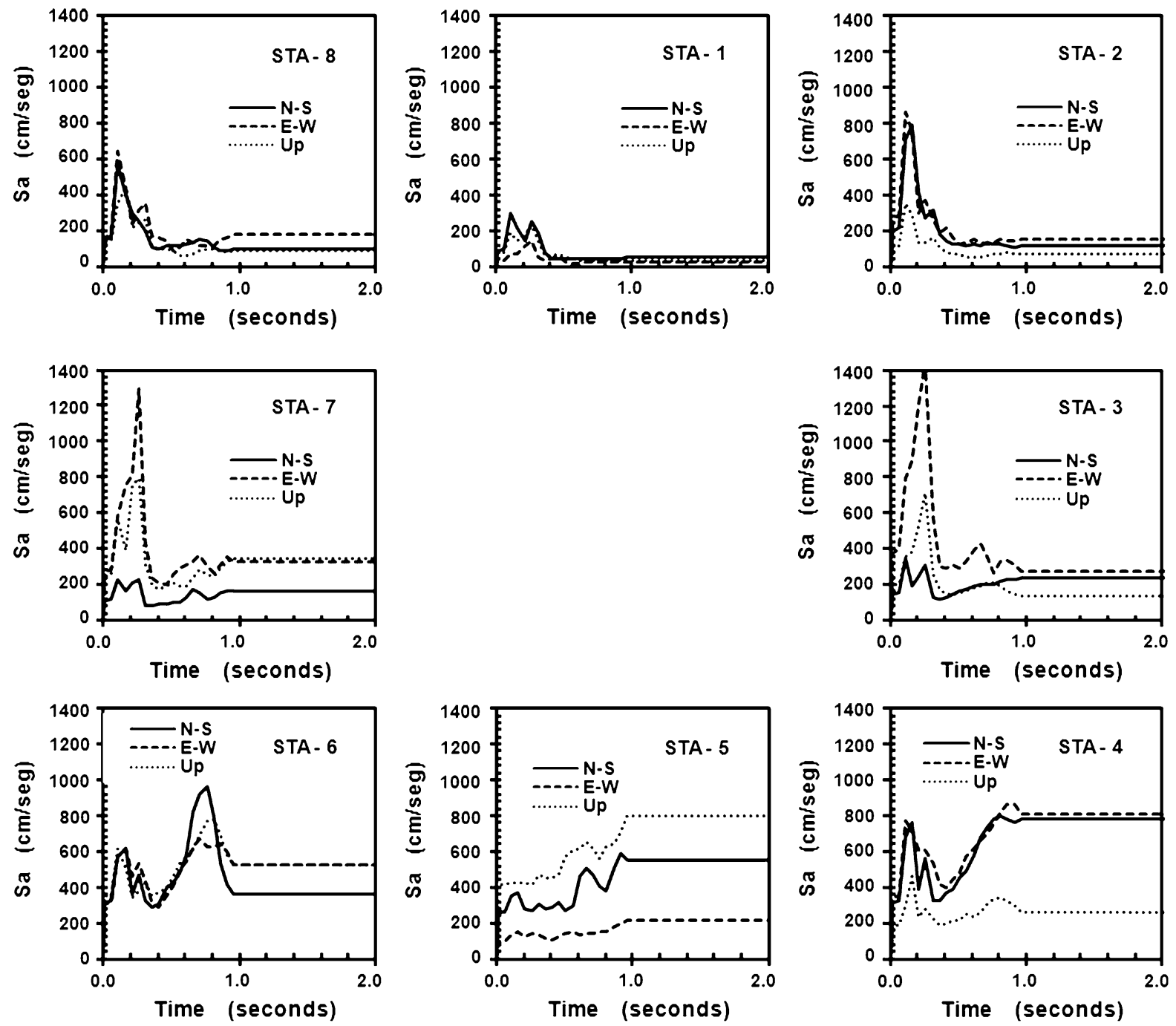

Figure 11

continued

A third order approximation was done assuming that ground motions due to the controlling earthquakes can be generated by a finite fault rupture embedded in a layered Earth, with a given slip distribution, focal mechanism and rupture velocity. A more detailed characterization of the ground motion was carried out by simulation of accelerograms and response spectra considering different locations of the earthquakes relative to the dam site and taking into account possible directivity effects. We then appreciated very important variations in the PGA and SA $(T)$ values as a function of the source-site azimuth. PGA is one of the important factors to take into account for seismic hazard assessment; however, these results show the importance of taking into account directivity effects on surface motions and should be considered as an important aspect in the estimations of seismic hazard.

Next steps to be carried out by the regional or national governments, for a more realistic estimation of the ground motion in Itoiz dam due to local earthquakes, should include topographical effects. This problem can be estimated with the knowledge of the geometry of the irregular topography, their elastic properties, and the application of numerical methods for wave propagation modeling in topographical 
structures such as boundary elements (see, e.g., SánCHEZ-SEsma et al. 1993; Luzón et al. 1997) or finite difference methods (see, e.g., Perkz-Ruz et al. 2005) among others. Moreover, the influence of strong motion rotations (TrifunaC 2009; GodinHo et al. 2009) produced by possible near earthquakes on the response of the surface topography should be evaluated as well.

\section{Acknowledgments}

We thank C. López and S. Limonchi for the help in the field campaigns. We wish to thank Confederación Hidrográfica del Ebro (CHE) for giving access to their facilities and to the seismic data. We also thank Instituto Geográfico Nacional (IGN), Spain, and the Réseau Accélérométrique Permanent (RAP), France, for providing seismic data of the region. This work was partially supported by Secretaría General para el Territorio y la Biodiversidad from Ministerio de Medio Ambiente, Rural y Marino, Spain, under grant 115/SGTB/2007/8.1, by EU with FEDER and by the research team RNM-194 of Junta de Andalucía, Spain. The work done by M.A.S. was under the auspices of a Contract Ramón y Cajal. Z. al Yuncha was in the initial stages of this research. The PSHA study was performed during the research stay of A.R.M. at the University of Almería, Spain.

\section{REFERENCES}

Abrahamson, N.A., and Sllva, W.J., (2007), Abrahamson \& Silva $N G A$ ground motion relations for the geometric mean horizontal component of peak and spectral ground motion parameters, PEER Report Draft v2, Pacific Earthquake Engineering Research Center, Berkeley, CA, pp 380.

AkKar, S., and Bommer, J.J., (2007a), Prediction of elastic displacement response spectra in Europe and the Middle East, Earthq Eng Struct Dyn 36: 1275-1301.

AkKar, S., and BOMMER, J.J., (2007b), Empirical prediction equations for peak ground velocity derived from strong motion records from Europe and the Middle East, Bull Seism Soc Am 97(2): 511-530.

Álvarez-Gómez, J.A., García-Mayordomo, J., Martínez-Díaz, J.J., and Capote, R., (2005), SeriesBuster: a Matlab Program to Extract Spatio-Temporal Series from an Earthquake Database, Computers and Geosciences, 31, 521-525.

Ambraseys, N.N., Simpson, K.A., and Bommer, J.J., (1996), Prediction of horizontal response spectra in Europe, Earthq Eng Dyn 25(4): 371-400.
Ambraseys, N.N., Douglas, J., SARMa, S.K., and Smit, P.M. (2005), Equations for the Estimation of Strong Ground Motions from Shallow Crustal Earthquakes Using Data from Europe and the Middle East: Horizontal Peak Ground Acceleration and Spectral Acceleration, Bulletin of Earthquake Engineering, 3, 1-53.

ARIAS, A. (1970). A measure of earthquake intensity". In R.J. Hansen, ed. Seismic Design for Nuclear Power Plants, MIT Press, Cambridge, Massachusetts, pp 438-483.

Benito, B., and Gaspar-Escribano, J. M., (2007), Ground motion characterization in Spain: context, problems and recent developments in seismic hazard assessment, Journal of Seismology Vol. 11: 433-452.

Benito, B., Gaspar-Escribano, J. M., Martínez-Díaz, J.J., Gómez, R., Canora, C. and Álvarez, J.A., (2008), Evaluación de la peligrosidad sísmica (emplazamientos en roca) Vol.l. Evaluación del Riesgo Sísmico en Navarra, Protección Civil de Emergencias de la Comunidad Foral de Navarra. Internal report. Berge-Thierry, C., Cotton, F., Scotti, O., Griot-Pommera, D.A., and Fukusmia, Y., (2003), New Empirical Response Spectral Attenuation Laws for Moderate European Earthquakes, J. Earthquake Eng. 7 (2), 193-222.

BudnitZ, R.J., Apostolakis, G., and Boore, D.M., (1997), Recommendations for Probabilistic Seismic Hazard Analysis: Guidance on Uncertainty and Use of Experts, NUREG/CR-6372, US Nuclear Regulatory Commission.

Boore, D.M., and Atkinson, G.M., (2007), Boore-Atkinson NGA ground motion relations for the geometric mean horizontal component of peak and spectral ground motion parameters, PEER Report 2007/01, Pacific Earthquake Engineering Research Center, Berkeley, CA, pp 234.

Bouchon, M., (1979), Discrete wave number representation of elastic wave field in three space dimensions, Journal of Geophysical Research, 84, 3609-3614.

BouchoN, M., and AKI, K., (1977), Discrete wave number representation of seismic source wave fields, Bulletin of the Seismological Society of America, 67, 259-277.

Cabañas, L, Benito, B, Cabañas, C, López, M, Gómez, P, Jiménez, ME, Álvarez, S (1999). Banco de Datos de Movimiento Fuerte del Suelo MFS. Aplicaciones, in: Ingeniería sísmica, edited by M. B. Benito, D. Muñoz, Física de la Tierra 11, 111-137.

CampBell, K.W., and Bozorgnta, Y., (2007), Campbell-Bozorgnia NGA ground motion relations for the geometric mean horizontal component of peak and spectra ground motion parameters, PEER Report 2007/02, Pacific Earthquake Engineering Research Center, Berkeley, CA, pp 240.

Chávez-García, F.J., Rodríguez, M., and Stephenson, W.R., (2005), An alternative approach to the SPAC analysis of microtremors: exploiting the stationarity of noise, Bull. Seism. Soc. Am., 95, 277-293.

Chávez-García, F.J., and Luzón, F., (2005), On the correlation of seismic microtremors, Journal of Geophysical Research-Solid Earth. Vol. 110, B11, B11313, doi:10.1029/2005JB003671.

Chávez-García, F.J., Luzón, F., Raptakis, D. and Fernández, J., (2007), Shear-wave velocity structure around Teide volcano: results using microtremors with the SPAC method and implications for interpretation of geodetic results, Pure and Applied Geophysics, 164, 697-720.

Chrou, B., and Youngs, R.R., (2006), Chiou-Youngs PEER-NGA empirical ground motion model for the average horizontal component of peak acceleration and pseudo-spectral acceleration for spectral periods of 0.01 to 10 seconds, PEER Report 
Draft, Pacific Earthquake Engineering Research Center, Berkeley, CA, 219 pp.

Colegio de Ingenieros de Camnos, Canales y Puertos (2005). Estudio sobre la Presa de Itoiz, Internal report. Confederación Hidrográfica del Ebro. http://www.chebro.es.

Colegio DE Geologos, (2005). Informe de supervisión de los estudios $Y$ análisis disponibles sobre la seguridad de la presa de Itoiz, Internal report. Confederación Hidrográfica del Ebro. http://www.chebro.es.

Daignières, M., Séguret, M., and Ecors Team, (1994). The Arzacq-western Pyrenees ECORS deep seismic profile, Publ. Eur. Assoc. Pet. Geol. 4, 199-208.

Dowrick, D.J., and RhoAdes, D. A., (2004), Relations Between Earthquake Magnitude and Fault Rupture Dimensions: How Regionally Variable Are They? Bulletin of the Seismological Society of America, Vol. 94, No. 3, pp. 776-788, June.

Drouet, S., Scherbaum, F., Cotton, F., and Souriau, A. (2007), Selection and ranking of ground motion models for seismic hazard analysis in the Pyrenees, J. Seismol. 11, 87-100.

Ecors Pyrenees Team, (1988). The ECORS deep reflection seismic survey. Nature $311,508-511$.

Gallart, J., Banda, E., and Daignières, M., (1981), Crustal structure of the Paleozoic axial zone of the Pyrenees and transition to the north Pyrenean zone, Ann. Geophys. 37 (3), 457-480.

GaRCíA-YAGÜE, A., (2004), Análisis de la sismicidad registrada en el entorno de la presa de Itoiz, Término municipal de Lónguida (Navarra), Internal report. Confederación Hidrográfica del Ebro. http://www.chebro.es.

GarcíA-Mayordomo, J., (2007), Metodologiás modernas en el análisis de peligrosidad siśmica para embalses, in Jornadas Técnicas sobre Estabilidad de Laderas en Embalses (Ed. Confederación Hidrográfica del Ebro), Memorias, 581-597, Zaragoza.

García-Mayordomo, J., and Insúa-Arévalo, J.M., (2010), Estudio Sismotectónico y de Actividad Tectónica Reciente en el entorno de la Presa de Itoiz (Navarra): Cálculo de la Peligrosidad Sísmica Mediante Técnicas Modernas, Internal report of the Instituto Geológico y Minero de España.

García-Sansegundo, J., (1993), Memoria y mapas geológicos a escala 1: 25.000 de la hoja $n^{\circ} 142$ (Aoiz), cuadrantes de Aoiz (I), Irurozqui (II), Monreal (III) y Domeño (IV), Diputación Foral de Navarra.

Godinho, L., Mendes, P.A., Tadeu, A., Cadena-Isaza, A., Smerzint, C., SÁnchez-Sesma, F.J., Madec, R. and Komatitsch, D. (2009). Numerical simulation of ground rotations along $2 D$ topographical profiles under the incidence of elastic waves, Bull. Seism. Soc. Am, Vol 99, No. 2B, pp 1147-1161.

Gứa Técnica de Segurmad de Presas. 1999. Volumen 3. Estudios Geológico-Geotécnicos y de prospección de materiales. Comité Nacional Español de Grandes Presas. ISBN: 84-89567-11-5.

Guía de Seguridad de Presas. 2005. Capítulo 7. Criterios básicos de seguridad. Colegio de Ingenieros en Caminos, Canales y Puertos (ISBN: 84-380-0298-6) y Comité Nacional Español de Grandes Presas (ISBN: 84-89567-15-8).

HATANAKA, M., (1960). Study on the earthquake-resistant design of gravity type dams, 2nd WCEE, Tokyo.

Herraiz-Sarachaga, M., (2005). Sismicidad Inducida por Embalses. - Consideraciones generales. Internal report. Confederación Hidrográfica del Ebro. http://www.chebro.es.
Herrmann, R.B., (1987). Computer programs in Seismology, Saint Louis University, 7 vols.

IDRISS IM (2007). Empirical model for estimating the average horizontal values of pseudoabsolute spectral accelerations generated by crustal earthquakes, PEER Report Draft, Pacific Earthquake Engineering Research Center, Berkeley, CA, pp 76.

INGENIERIA DEL SUELo, S.A., (2005). Informe de auscultación de la presa de Itoiz, Tomo I: Memoria. (Madrid). Internal report. Confederación Hidrográfica del Ebro. http://www.chebro.es.

Instituto JAUME AlmERA (2005). Registro de los sismógrafos instalados en Itoiz, Internal report. Confederación Hidrográfica del Ebro. http://www.chebro.es.

Jiménez, A., Tiampo, K.F., Posadas, A., Luzón, F., and Donner, R., (2009). Analysis of complex networks associated to seismic clusters near the Itoiz reservoir dam, European Physical Journal Special topics, 174, 181-195.

Lussou, P., Fukushima, Y., Bard, P.Y., and Cotton, F., (2001) Seismic design regulation codes: contribution of Knet data to site effect evaluation. J Earthq Eng 5, 13-33.

Luzón, F., Sánchez-Sesma, F.J., Rodríguez-Zúñiga, J.L., A. M. Posadas, García, J. M., J. Martín, M. D. Romacho and NAvarro, M. (1997). Diffraction of $P, S$ and Rayleigh waves by three-dimensional topographies, Geophys. J. Int., Vol. 129, pp. 571-578.

Luzón, F., García-Jerez, A., Santoyo, M.A., and SÁnchez-Sesma, F. J., (2009). A hybrid technique to compute the pore pressure changes due to time varying loads: application to the impounding of the Itoiz reservoir, northern Spain, In POROMECHANICS-IV, Eds. H. Ling, A. Smyth, and R. Betti, DEstech Publications, Inc., Lancaster, Pennsylvania. ISBN:978-1-60595-006-8., pp. 11091114.

Luzón, F., García-Jerez, A., Santoyo, M.A., and Sánchiez-Sesma, F.J., (2010). Numerical modelling of pore pressure variations due to time varying loads using a hybrid technique: the case of the Itoiz reservoir (Northern Spain), Geophysical Journal International, doi:10.1111/j.1365-246X.2009.04408.x.

Mrkumo, T., Mryatake, T., and Santoyo, M.A., (1998). Dynamic rupture of asperities and stress change during a sequence of large interplate earthquakes in the Mexican subduction zone, Bull. Seism. Soc. Am., 88, 686-702.

Moptma (1996). Orden de 12 de marzo de 1996 por la que se aprueba el Reglamento técnico sobre Seguridad de Presas y Embalses, Boletín Oficial del Estado núm. 78 de sábado 30 de marzo de 1996, Spain.

Morikawa, H., Sawada, S., and Akamatsu, J., (2004), A method to estimate phase velocities of Rayleigh waves using microseism simultaneously observed at two sites, Bull. Seism. Soc. Am., 94, 961-976.

NCSE-02, (2002). NORMA DE LA CONSTRUCCTÓN SISMORRESISTENTE española (NCSE02) (2002). Real Decreto 997/2002, de 27 de septiembre, por el que se aprueba la norma de construcción sismorresistente: parte general y edificación (NCSR-02), Boletín Oficial del Estado (BOE) número 244 de 11/10/2002, páginas 35898 a 35967.

NuClenor S.A. (1983). Estudio de Revisión de la Calificación Sísmica del Emplazamiento de la central nuclear de Santa María de Garoña, Temas SEP II- 4. 3 volúmenes.

Ordaz, M., Agullar, A., and Arboleda, J. (2007), Program for computing seismic hazard, CRISIS2007, Universidad Nacional Autónoma de México. 
Pérez-Rưz, J.A., Luzón F. and García-Jerez, A. (2005). Simulation of an Irregular Free Surface with a Displacement Finite-Difference Scheme. Bull. Seism. Soc. Am. Vol. 95, (6), 2216-2231.

Pous, J., Muñoz, J.A., Ledo, J.J., and LiesA, M., (1995). Partial melting of subducted continental lower crust in the Pyrenees. Journal of the Geological Society, London, 152, 217-220.

Prospeccion e Ingeniería (1992). Estudio Sísmico de Navarra, Gobierno de Navarra Servicio de Protección Civil, Memoria 103 pp., 7 planos +5 Apéndices.

Puigdefabregas, C., Rojas, B., Sánchez-Carpintero, I., and Valle DE LeRChund, J., (1978). Memoria y Mapa Geológico de España, E. 1:50.000, $2^{\text {a }}$ ser., Hoja $n^{\circ} 142$ (Aoiz). Inst. Geol. Min. Esp.

RAPTAKIS, D., and MAKRA, K., (2010). Shear wave velocity structure in western Thessaloniki (Greece) using mainly alternative SPAC method, Soil Dynamics and Earthquake Engineering 30 (2010) 202-214.

RUEDA, J., (2005). Informe sobre terremotos ocurridos en Itoiz, (Navarra) en septiembre de 2004, Internal report, Instituto Geográfico Nacional, Madrid.

RuedA, J., and MeZCUA, J., 2005. Near-real-time seismic momenttensor determination in Spain, Seismological Research Letters. $76,455-465$.

Ruz, M., Gaspà, O., Gallart, J., Díaz, J., Pulgar, J.A., GarcíaSAnsegundo, J., Ópezfernández, C., and González-Cortina, J.M., (2006a). Aftershocks series monitoring of the September 18, 2004, $M=4.6$ earthquake at the western Pyrenees: A case of reservoirtriggered seismicity? Tectonophysics, 424, 223-243.

Ruzz, M., Gallart, J., Díaz, J., Olmera, C., Pedreira, D., López, C., Gonzálezcortina, J.M., and Pulgar, J.A., (2006b). Seismic activity at the western Pyrenean edge, Tectonophysics, 424, $217-235$.

Sabetta, F., and Pugliese, A., (1996) Estimation of response spectra and simulation of nonstationary earthquake ground motions, Bull. Seism. Soc. Am., 86(2): 337-352.

Sánchez-Sesma, F.J., Ramos-Martínez, J. and Camplloo, M. (1993). An indirect boundary element method applied to simulate the seismic response of alluvial valleys for incident- $P$, incident $-S$ and Rayleigh-waves, Earthquake Engineering \& Structural Dynamics, 22 (4), 279-295.
Santoyo, M.A., García-Jerez, A., and Luzón, F., (2010), A Subsurface Stress Analysis and its Possible Relation with Seismicity Near the Itoiz Reservoir, Navarra, Northern Spain, Tectonophysics, doi:10.1016/j.tecto.2009.06.022.

Secanell, R., Bertil, D., Martin, CH., Goula, X., Susagna, TH., Tapia, M., Dominique, P., Carbon, D., and Fleta, J., (2008). Probabilistic seismic hazard assessment of the Pyrenean region, J Seismol. doi:10.1007/s10950-008-9094-2.

Singh, S. K., and ORDaZ, M., (1994). Seismic Energy Release in Mexican Subduction Zone Earthquakes, Bull. Seism. Soc. Am, Vol. 84, No. 5, pp. 1533-1550.

Souriau, A., and Granet, M., (1995). A tomographic study of the lithosphere beneath the Pyrenees from local and teleseismic data, Journal of Geophysical Research, 100(B9), 18117-18134.

Souriau, A., and Pauchet, H., (1998). A new synthesis of Pyrenean seismicity and its tectonic implications, Tectonophysics 290 , 221-244.

Sourtau, A., Sylvander, M., Rigo, A., Fels, J.F., Douchain, J. M. and Ponsolles, C., (2001), Sismotectonique des Pyrénées: principales contrainters sismologiques, Bull.Soc.géol.France, 172(1), 25-39.

STEPP, J.C., (1972) Analysis of completeness of the earthquake sample in the Puget Sound area and its effect on statistical estimates of earthquake hazard, In: Proceedings the 2nd International Conference on Microzonation, pp 897-910.

TAPIA, M. (2006) Desarrollo y aplicación de métodos avanzados para la caracterización de la respuesta sísmica del suelo a escala regional y local, $\mathrm{PhD}$ Tesis, Universitat Politecnica de Catalunya, Barcelona.

Tinti, S. and Mulargia, F. (1985) Completeness analysis of a seismic catalog, Annales Geophysicae 3(3), 407-414.

TRIFUNAC, M.D. (2009). The role of strong motion rotations in the response of structures near earthquake fault, Soil Dynamics and Earthquake Engineering, 29, 382-393.

Wells D. L. and K. J. Coppersmth (1994). New Empirical Relationships among Magnitude, Rupture Length, Rupture Width, Rupture Area, and Surface Displacement, Bull. Seism. Soc. Am, Vol. 84, No. 4, pp. 974-1002. 